Article

\title{
Morphological Variability of Submarine Mass Movements in the Tectonically-Controlled Calabro-Tyrrhenian Continental Margin (Southern Italy)
}

\author{
Daniele Casalbore ${ }^{1,2, *}$, Alessandro Bosman ${ }^{1}$, David Casas ${ }^{3}$, Francesco Chiocci ${ }^{1,2}$, \\ Eleonora Martorelli ${ }^{1}$ and Domenico Ridente ${ }^{1}$ \\ 1 Istituto di Geologia Ambientale e Geoingegnera, Consglio Nazionale delle Ricerche, Rome 00015, Italy; \\ alessandro.bosman@uniroma1.it (A.B.); francesco.chiocci@uniroma1.it (F.C.); \\ eleonora.martorelli@uniroma1.it (E.M.); domenico.ridente@cnr.it (D.R.) \\ 2 Department of Earth Sciences, Sapienza University of Rome, Rome 00185, Italy \\ 3 Instituto Geologico y Minero de España (IGME), Rios Rosas 23, 28003 Madrid, Spain; d.casas@igme.es \\ * Correspondence: daniele.casalbore@uniroma1.it
}

Received: 2 November 2018; Accepted: 10 January 2019; Published: 15 January 2019

check for updates

\begin{abstract}
The analysis of high resolution morpho-bathymetric data on the Calabro Tyrrhenian continental margin (Southern Italy) enabled us to identify several morphological features originated by mass-wasting processes, including shallow gullies, shelf-indenting canyons and landslides. Specifically, we focus our attention on submarine landslides occurring from the coast down to $-1700 \mathrm{~m}$ and affecting variable areas from thousands of square meters up to few tens of square kilometers. These landslides also show a large variability of geomorphic features which seems strictly related to the physiographic/morphological domains where the landslide formed. Tectonically-controlled scarps and canyon flanks are typically characterized by several coalescent and nested landslides, with diameters ranging from hundreds to a few thousands of meters. Canyon headwalls are commonly characterized by a cauliflower shape due to an array of small (diameters of tens of meters) and coalescent scars. In all these sectors, disintegrative-like landslides dominate and are generally characterized by a marked retrogressive evolution, as demonstrated by their morphology and comparison of repeated bathymetric surveys at the canyon headwall. Only in the lower part of tectonically-controlled scarps, a few cohesive-like and isolated landslides are present, indicating the main role of slope gradients and height drop in controlling the post-failure behavior of the mobilized material. Open slopes are generally characterized by large-scale (diameters of thousands of meters) and isolated scars, with associated landslide deposits. A peculiar case is represented by the Capo Vaticano Scar Complex that affected an area of about $18 \mathrm{~km}^{2}$ and is characterized by an impressive variability of landslide morphologies, varying also at short distance. The large extent and variability of such scar complex are thought to be associated with the occurrence of a mixed contouritic-turbidite system. By integrating the high-resolution morpho-bathymetric dataset with the results of previous studies, we discuss the main factors controlling the variability in size and morphology of submarine landslides developed in a tectonically-controlled setting and provide preliminary considerations on their potential geohazard in a densely populated coastal area.
\end{abstract}

Keywords: landslide scars; canyon; fault escarpments; contourite deposits; multibeam; continental slope 


\section{Introduction}

Geomorphic features associated with submarine mass movements are ubiquitous in all marine settings at very different depths and slope steepness [1-3]. Their study has significantly increased in the last two decades in relation to the technological advances both in seafloor imagery system and seismic techniques as well as to the growing interest for their hazard potential [4,5]. These events can directly impact offshore or coastal infrastructures [6,7] or cause local but destructive tsunami waves, as for instance observed at Nice in 1979 [8] and Stromboli in 2002 [9]. The tsunamigenic potential of mass movements greatly depends on the water depth and size of the slope failure, even if the initial acceleration and velocity play a significant role [5]. Large-scale mass-movements (volumes in the order tens or thousands of cubic kilometers) are capable to produce regional tsunamis with wave heights of tens of meters. Even if smaller landslides in shallow-water areas have been often overlooked, they could be more hazardous than the larger ones. They typically occur more frequently than the larger events and can generate local but destructive tsunamis [7] if they occur in shallow-water sectors. Small landslides are very common in geologically-active margins, where mass-wasting processes can affect percentages of seafloor areas higher than $50 \%$ and up to $90 \%$ in some cases [10]. This is also the case of the tectonically-active Calabro-Tyrrhenian margin encompassed between Cape Vaticano to the north and the Messina Strait to the south (Figure 1). This margin formed during the opening of the back-arc Tyrrhenian Basin, in turn controlled by the NW-oriented subduction of the Ionian crust beneath the Calabrian Arc [11] (Figure 1 inset). The Calabrian Arc is formed by allochthonous terrains of the Alpine domain (Kabilo-Calabride nappes, KCC in the inset of Figure 1), overriding the Apennine units to the SE and N (AMC in the inset of Figure 1). Particularly, it is made up of deformed metamorphic-crystalline basement rocks, discontinuously covered by Mesozoic limestones and Cenozoic flysch deposits [12].

The Calabrian Arc and offshore areas have been largely affected by extensional faults since the Miocene [12,13] (violet lines in Figure 1). Major extensional tectonics (as the SW-NE Scarps in Figure 1) in the continental margin have been quiescent since at least the Late Pliocene-Early Pleistocene [12], whereas rifting is still active in the emerged Calabrian Arc. This recent tectonic activity is able to produce large and frequent earthquakes, such as the 1783 seismic sequence, the Capo Vaticano 1905 or the Messina 1908 events [14]. 


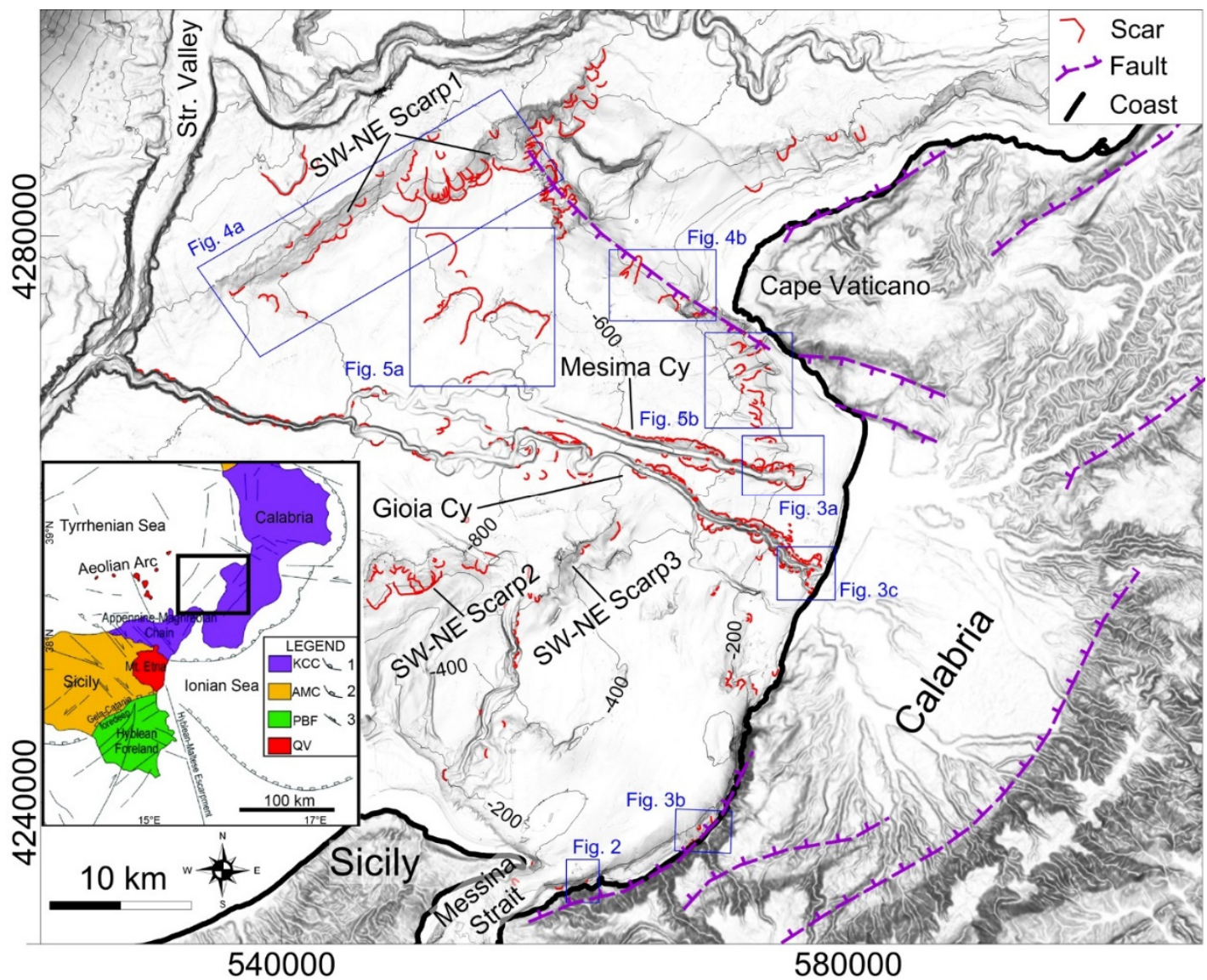

Figure 1. Shaded relief map (azimuthal light) of the Calabro-Tyrrhenian continental margin encompassed between Cape Vaticano and the Messina Strait (location in the inset), with the indication of the recognized landslide scars (red lines from [15]), the main faults (violet lines from [16]) and the location of the following figures (blue boxes). The inset shows a simplified structural sketch of Southern Italy (modified from [17]); KCC: Kabilo-Calabride Chain Units; AMC: Appennine-Maghrebian Chain Units; PBF: Pelagian Block Foreland Units; QV: Quaternary Volcanoes; 1 regional overthrust of the Kabilo-Calabride units upon the Apennine-Maghrebian; 2 external front of the Apennine-Maghrebian Chain upon the Foreland units and the External Thrust System Chain; 3 main normal and strike-slip faults.

The coastal area is also affected by relevant uplift rates (rates up to $2 \mathrm{~mm}$ per year) since the Middle Pleistocene [18]. Because of this tectonic uplift, the continental shelf is commonly narrow and steep (Figure 1), and it receives a large amount of sediment by subaerial erosion of the coastal range. This latter is, in fact, carved by a network of steep and short river courses, locally named Fiumara [19], characterized by a torrential regime, during which flash-flood sedimentary gravity flows are often generated [20-22].

Due to the concomitant occurrence of all these preconditioning and triggering factors, this continental margin is largely affected by widespread mass-wasting processes ranging at different spatial scales during time. A basin-scale mass-transport deposit (the Nicotera Slump, [23]) covering an area of $636 \mathrm{~km}^{2}$ and with an estimated volume of about $30 \mathrm{~km}^{3}$ is recognizable in the continental slope stratigraphy. The Gioia-Mesima canyon-channel system, draining the entire continental margin, is well recognizable along with over 400 landslide scars on the morpho-bathymetric data (Figure 1); these landslide scars affected an area of $>85 \mathrm{~km}^{2}$ and mobilized approximately $1.4 \mathrm{~km}^{3}$ of sediment [15].

In this paper, our aim is to outline the large variability of geomorphic features related to the submarine mass movements along the Calabro-Tyrrhenian Margin through a review of selected case studies. This dataset is used to discuss the main factors in controlling the failure and post-failure 
behavior of the recognized landslides as well as a preliminary assessment of their tsunamigenic potential. More broadly, this review highlights the importance and need of marine geomorphological studies in the reconstruction of tectonically-controlled continental margin evolution, where submarine slope failures are a prominent component and can represent a major hazard for coastal communities and offshore infrastructures.

\section{Data and Methods}

The morpho-bathymetric data presented in this study were collected during several oceanographic cruises performed onboard Urania and Minerva1 vessels (National Research Council) and small boats for shallow-water surveys. Data were acquired between the coast and $2000 \mathrm{~m}$ water depth using multibeam systems (Kongsberg and Teledyne Reson) working at frequency of $50-455 \mathrm{kHz}$ in order to gain the best resolution for each bathymetric interval. Data were processed using Caris Hips \& Sips software and were gridded at variable cell-size, ranging from $1 \mathrm{~m}$ in shallow-waters to $25 \mathrm{~m}$ in deep-waters. The subaerial Digital Elevation Models, presented in some figures, were derived from Advanced Spaceborne Thermal Emission and Reflection Radiometer Data (downloadable from the website https://asterweb.jpl.nasa.gov/gdem.asp). Aerial photos draped over the subaerial Digital Elevation Models were downloaded from the world imagery provided by ARCGIS (website https://www.arcgis.com/home/item.html).

The methodology used for this work mainly consists of the analysis and comparison of the main geomorphic features related to landslide scars and deposits on the Calabro Tyrrhenian continental margin. The distribution and variability of these geomorphic features are not random but concentrate in some areas, reflecting the large-scale geomorphological and tectonic setting of the continental margin, characterized by submarine canyons (3.1), tectonically-controlled escarpments (3.2) and open slopes (3.3). For each area, we describe the most common and/or best examples of landslide(s) based on a series of published and unpublished examples. Moreover, we summarize the size (minimum /maximum diameters and areas) of the recognized landslide scars in each area (Table 1).

Table 1. Maximum (max) and minimum ( $\min$ ) values of areas and diameters associated with the landslide scars recognized in each physiographic/morphological domain present in the study area using multibeam bathymetry. CVSC: Capo Vaticano Scar Complex.

\begin{tabular}{|c|c|c|c|c|c|c|}
\hline Setting & $\begin{array}{l}\text { Diameter } \\
\text { min. (m) }\end{array}$ & $\begin{array}{l}\text { Diameter } \\
\text { max. (m) }\end{array}$ & $\begin{array}{c}\text { Area min. } \\
\left(\mathrm{km}^{2}\right)\end{array}$ & $\begin{array}{c}\text { Area max. } \\
\left(\mathrm{km}^{2}\right)\end{array}$ & $\begin{array}{c}\text { Slope Gradients } \\
\text { Range }\left({ }^{\circ}\right)\end{array}$ & $\begin{array}{l}\text { Average Slope } \\
\text { Gradients }\left({ }^{\circ}\right)\end{array}$ \\
\hline Canyon (headwall) & 50 & 200 & 0.004 & 0.3 & $(10-19)$ & 14 \\
\hline Canyon (flank) & 130 & 1150 & 0.02 & 0.7 & $(4-23)$ & 8 \\
\hline Tectonically-controlled Scarp 1 & 520 & 1900 & 0.05 & 3.2 & $(8-20)$ & 13 \\
\hline Tectonically-controlled scarp 2 & 350 & 1764 & 0.03 & 2 & $(6-11)$ & 10 \\
\hline Tectonically-controlled scarp 3 & 150 & 1400 & 0.06 & 1 & $(5-14)$ & 9 \\
\hline
\end{tabular}

By this, we try to constraint the main factors (slope gradients, height drop, degree of confinement, tectonic influence, lithological variability) controlling the development and emplacement of the slope failures in the different areas (4.1).

Other types of submarine geomorphic features referable to mass movements in the study area are blocky deposits associated with coastal rocky failures. Such deposits are briefly introduced below, as they can have a significant tsunamigenic potential (4.2). The most striking example occurs off the Scilla village, where a cluster of hummocky reliefs, with a diameter of 20-180 m and height of 2-30 m with respect to the surrounding seafloor is present at the base of the continental slope between -270 and -305 m (Figure 2). These deposits were related to the Mt. Pacì 1783 subaerial landslide, triggered during the second main shock of the 1783 earthquake sequence [24]. However, it is noteworthy that the recognition of a submarine depression coaxial with the subaerial one (Figure 2) could suggest the development of a larger subaerial-submarine slope failure or the occurrence of multiple events [25]. 
Similar blocky deposits associated with rocky coastal landslides have been found also northward, close to Palmi village, indicating the susceptibility of the study area to such processes [25], as briefly discussed in Section 4.2.

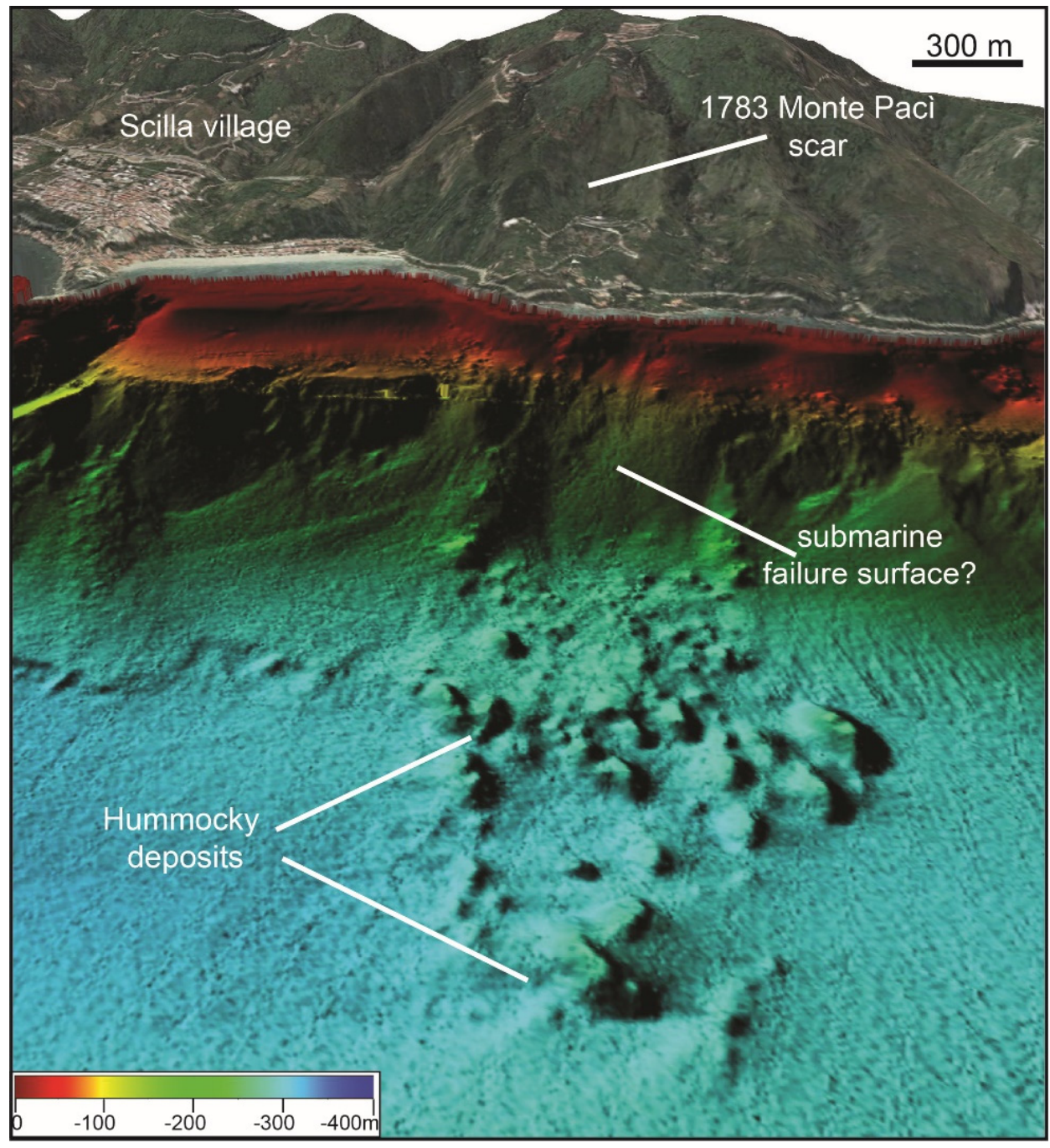

Figure 2. 3-D view of the hummocky deposits related to the 1783 Monte Pacì rocky and tsunamigenic landslide occurring off Scilla village, for location see Figure 1.

\section{Results}

\subsection{Submarine Mass Movements on Submarine Canyons}

In the study area, a main canyon-channel system is formed by the Gioia and Mesima shelf-indenting canyons (Figures 1 and 3; [13,26]). Minor channels are also recognizable, such as the Bagnara Channels in the southern part (Figures 1 and 3b). Landslide scars are largely recognizable both at the headwall and flanks of the Gioia-Mesima canyon-channel system, commonly showing a semicircular and regular shape (Figure 3). Differently, morphological evidence of clear deposits associated with landslide deposits is often lacking on the multibeam bathymetry. Landslide scars occurring along the canyon flanks generally have a larger size (diameters ranging from few hundreds of meters up to $\approx 1000 \mathrm{~m}$; Figure $3 \mathrm{a}$ and $\mathrm{c}$ and Table 1 ) with respect to the canyon headwall. These scars are often coalescent and nested with each other, forming a linear to sinuous array of instability features following the main path of the canyon. In some cases, extensional ridges and detached blocks are recognizable within the landslide scars located in the upper (or external) part of the canyon flanks (Figure 3a), indicating that the mobilized material was not totally evacuated during the failure event. 
Differently, the canyon headwall is often characterized by a cauliflower shape, formed by small (50-200 m wide, Table 1) and coalescent scars, which affect the littoral wedge at depths $<15 \mathrm{~m}$, thus suggesting a recent erosion (Figure 3b,c). Most of these landslide scars show a sub-rounded shape in plan-view and an overall smooth seafloor, suggesting the complete mobilization of the material during the failure event. The comparison between geo-referenced aerial photos and time-lapse multibeam bathymetries collected in the last decade at the headwall of the Gioia Canyon and Bagnara channels has also evidenced the occurrence of repeated retrogressive landslide scars with maximum diameters of a few tens of meters [25,27].

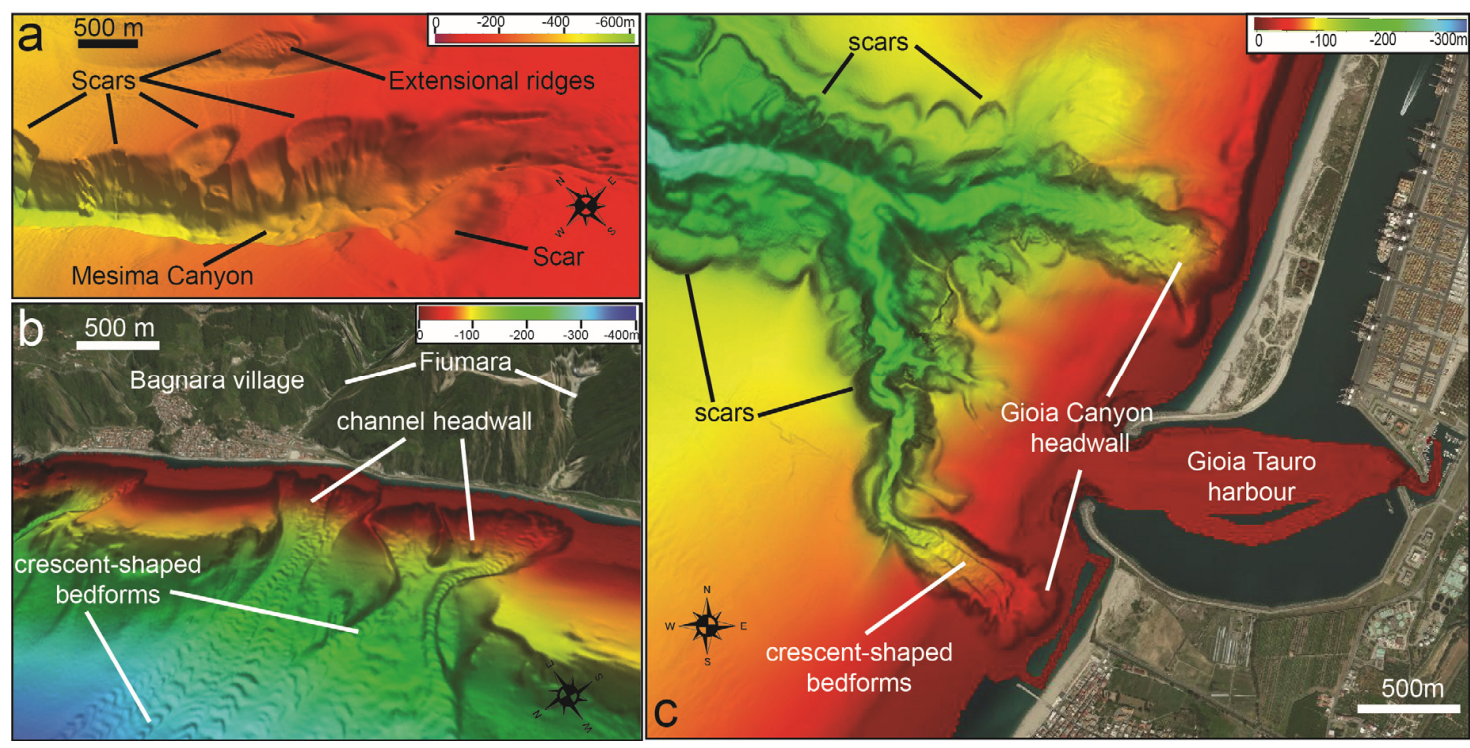

Figure 3. (a) 3-D view of the coalescent landslide scars affecting the outer flanks of the Mesima Canyon (location in Figure 1); note also the presence of extensional ridges within a landslide scars affecting a small channel. (b) 3-d view of the Bagnara Channels (location in Figure 1), where a cauliflower headwall formed by small landslide scars is recognizable along with coaxial trains of crescent-shaped bedforms. (c) Shaded relief of the upper reach of Gioia Canyon head (location in Figure 1), formed by two branches that isolate the entrance of the Gioia Tauro harbor. Note the cauliflowers shape of the southern headwall of the Gioia Canyon as well as the coalescent and nested landslides scars present along the flanks of the Gioia Canyon.

These smaller landslides can mobilize volumes comprised between 5.000 and $50.000 \mathrm{~m}^{3}$ and are able to produce a coastal retreat of the littoral wedge in the order of tens of meters for each event. Landslide deposits are not recognizable at the base of the scars of the canyon headwall, whereas channelized features are often present. These erosive features are commonly characterized by the occurrence of coaxial trains of arcuate or crescent-shaped bedforms, with wavelength of tens to hundreds of meters and amplitude of a few meters (Figure 3b,c).

\subsection{Submarine Mass Movements on Tectonically-Controlled Escarpments}

Several tectonically-controlled scarps are present in the area. One of the most prominent morpho-structural features of the area is the Capo Vaticano ridge extending down to $1000 \mathrm{~m}$ water depth (Figure 1). Particularly, the SW flank of this ridge is formed by a linear, steep (up to $18^{\circ}$ ) and up to $300 \mathrm{~m}$ high escarpment, indicating a tectonic control on its development (Figure $4 \mathrm{~b}$ and dashed violet line in Figure 1). Downslope, the Cape Vaticano ridge is cut by a $20 \mathrm{~km}$ long and few hundred meters high fault scarp between -1000 and $-1400 \mathrm{~m}$, oriented along a SW-NE direction (Scarp1 in Figures 1 and 4a). Minor SW-NE escarpments are also present between -800 and $-600 \mathrm{~m}$ in the SW part of the study area (Scarps 2 and 3 in Figure 1), even if they are less steep and high compared to the previous one (Table 1). 
Most part of these escarpments are largely affected by nested and coaxial landslides scars, having diameters ranging from some hundreds to few thousands of meters (Figure 4a and Table 1). The plan-view shape of these scars is variable from semi-circular to elongated along slope (Figure 4); deposits associated with these landslide scars are difficult to recognize on morpho-bathymetric data, except for a few isolated landslide scars occurring in the lower part of the escarpments (Figure 4b). Specifically, two main scars with associated deposits can be recognized on the SW flank of Cape Vaticano ridge: the first scar (Scar1 in Figure 4b) shows an elongated shape $(1800 \times 600 \mathrm{~m})$, with a steep and $20 \mathrm{~m}$ high head-scarp. Landslide deposits associated with Scar1 cover an area of $1.5 \mathrm{~km}^{2}$ and have an average thickness of $10 \mathrm{~m}$, displaying a smooth or slightly rough superficial morphology. The second scar (Scar2 in Figure 4b) shows a semicircular shape, with a diameter of about $1.3 \mathrm{~km}$; the head-scarp has a height of $15 \mathrm{~m}$ and slope gradients of $33^{\circ}$. Landslide deposits associated with Scar2 cover an area of $1.56 \mathrm{~km}^{2}$, with an average thickness of $12 \mathrm{~m}$; their morphology is quite rough, with the occurrence of small ridges in the distal part that could be interpreted as pressure ridges (Figure 4b). Both scars have an overall smooth surface, with the preservation of small extensional ridges and/or detached slab of sediments within them (Figure $4 b$ ).
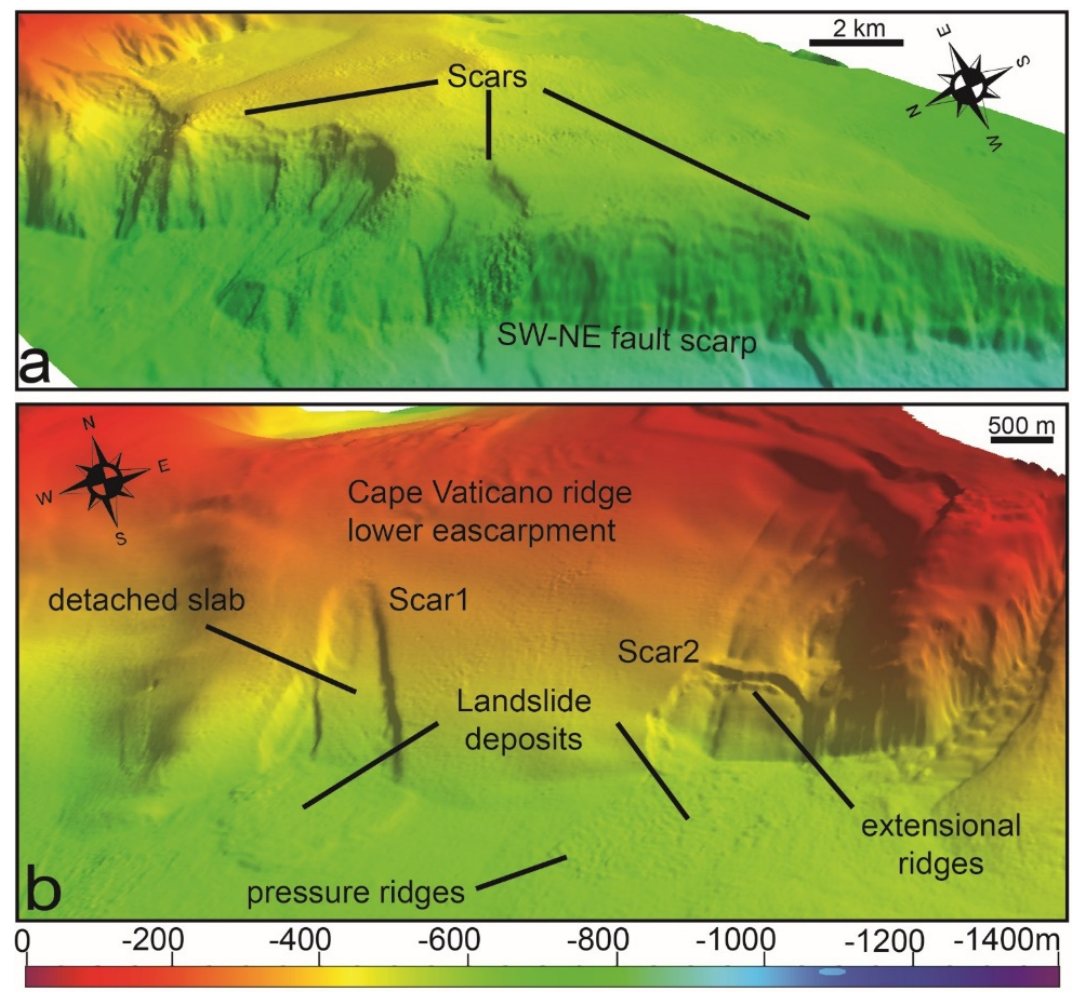

Figure 4. (a) 3-D view of the SW-NE tectonically-controlled escarpment recognized in the lower continental slope off Capo Vaticano ridge (for location see Figure 1), largely affected by nested and coalescent disintegrative-like landslides. (b) 3-D view of the lower part of the tectonically-controlled escarpment forming the SW flank of Cape Vaticano ridge (for location see Figure 1), where isolated and cohesive-like landslide scars (Scars1 and 2) with associated deposits are recognizable.

\subsection{Submarine Mass Movements on Open Slopes}

Based on multibeam bathymetry, relatively few landslides can be observed on the open slope sectors, even if they often have the largest size among all the recognized landslides (Figure 1 and Table 1). Particularly, three large landslides were identified on the continental slope (slope gradients of $2^{\circ}-5^{\circ}$, Table 1) comprised between Cape Vaticano and the Mesima Canyon between -700 and $-1000 \mathrm{~m}$ (Figure 5a). This sector is adjacent to the Capo Vaticano ridge but can be considered an open slope setting as minor tectonic control is indicated by seismic profiles [28]. The first scar (Scar3 in Figure 5a) 
is approximately $3.5 \times 4 \mathrm{~km}$ and has a head-scarp with height of 20-60 $\mathrm{m}$ (on average $35 \mathrm{~m}$ ) and slope gradients of $20^{\circ}-40^{\circ}$. Small blocks and extensional ridges (Figure $5 \mathrm{a}$ ) are present at the base of the main head-scarp, indicating the occurrence of material that is not completely evacuated from the scar. Downslope, the detached landslide mass is recognizable on the bathymetry and mostly confined within the landslide scar. Seismic profiles show, in fact, that landslide deposits are downslope confined from the northern levee of the Mesima Canyon [28]. The second scar (Scar4 in Figure 5a) is approximately $2 \times 4 \mathrm{~km}$ and its head-scarp is characterized by an average height of $25 \mathrm{~m}$, with slope gradients of approximately $20^{\circ}$. The scar shows an overall smooth morphology and no clear landslide deposits are recognizable on the bathymetry, indicating the total evacuation of the mobilized material (Figure 5a). The third scar (S5 in Figure $5 \mathrm{a}$ ) is $1.7 \times 2.7 \mathrm{~km}$, displaying an overall subdued relief, with a 4-15 m high head-scarp.

Besides these landslides, a large landslide complex is recognizable in the upper continental slope off Cape Vaticano (and for this reason named Capo Vaticano Scar Complex, CVSC hereafter, [29]) between $-190 \mathrm{~m}$ and $-500 \mathrm{~m}$ (Figures 1 and $5 \mathrm{~b}$ ). The CVSC covers an area of about $18 \mathrm{~km}^{2}$, with an estimated mobilized volume of approximately $175 \times 10^{6} \mathrm{~m}^{3}$ [29]. The CVSC is formed by four main landslide scars, having 10-25-m high head-scarps and several minor 2-5-m high head-scarps. It is noteworthy that the landslide morphology is highly variable along the CVSC, with the northern part mostly dominated by scars showing a rugged morphology due to material not completely evacuated during the failure, such as extensional ridges parallel to the main head-scarp (Figure 5b). On the contrary, the southern part of CVSC is mostly characterized by coaxial and tabular scars (forming a staircase of detached slabs of sediments, Figure 5b), having an overall smooth appearance and affecting the steep seaward side of a contourite drift. At the foot of the CVSC, rough morphology associated with coalescent and intersecting landslide deposits is present, including pressure ridges, blocks, and erosional remnants (Figure $5 b$ ).
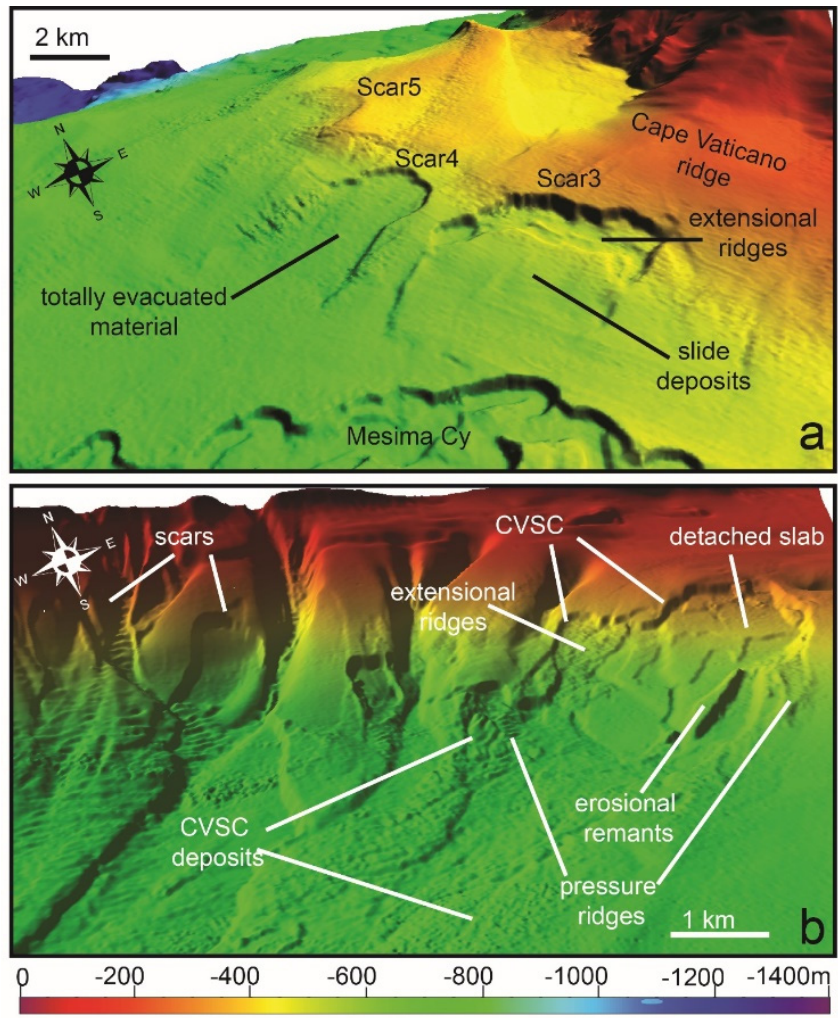

Figure 5. 3-D view of (a) the landslide scars affecting the open continental slope encompassed between Cape Vaticano ridge and Mesima Canyon and (b) the Capo Vaticano Scar Complex (CVSC) mostly affecting contourite deposits formed on the upper continental slope. For location see Figure 1. 


\section{Discussion}

\subsection{Distribution and Variability of Submarine Mass Movements and Related Controlling Factors}

The previous section evidenced the widespread distribution and variability of landforms associated with submarine mass movements in the sector of the Calabro-Tyrrhenian margin comprised between the Cape Vaticano and the Messina Strait, where semi-circular to elongated landslides scars, with variable size and morphology are present. Even if landslide morphology and distribution can be controlled by several factors and processes, varying in space and time (e.g., slope gradients, fall height, lithological characteristics, tectonic activity, sediment supply, pore water overpressure, cyclic load induced by earthquakes or waves, flank undercutting due to turbidity currents), it is noteworthy that most of the observed variability seems to be strictly related to different physiographic/morphological domains where the landslide formed.

Based on their morphology and distribution, three main types of submarine landslides can be recognized: (1) rocky coastal/shallow-water failures associated with cluster of hummocky deposits (not discussed in this section, because they are associated with coastal landslides); (2) a linear, sinuous or cauliflower array of disintegrative-like landslide along canyons and tectonically-controlled escarpments; (3) large-size and isolated landslides on open slopes. In this classification scheme, the CVSC represents a peculiar case of a large complex of coalescent and nested (disintegrativeand cohesive-like) landslide scars developed on the upper continental slope, where a mixed turbidite-contourite system is present [29].

\subsubsection{Disintegrative-like Landslides along Canyons and Tectonically-Controlled Scarps}

This type of slope failure mostly occurs along canyons, accounting for more than half of the total observations (59\%), even if they are generally of small- and medium-size, contributing only to the $5.2 \%$ of the mobilized sediment volume [15]. Another main cluster of small- and medium-size, disintegrative-like landslide scars is observed along the tectonically-controlled scarps affecting the area. The overall small size of these failures can be mostly related to the steep slope gradients (values ranging from $10^{\circ}$ to $23^{\circ}$, Table 1 and Figure 6) occurring in canyons and tectonically-controlled escarpments coupled with the frequent seismicity that characterizes the study area.

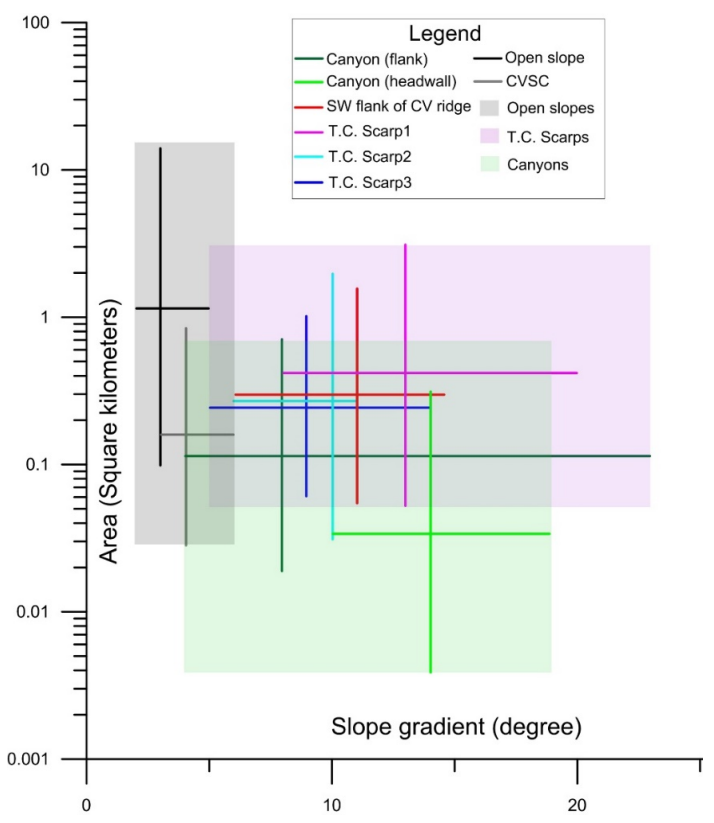

Figure 6. Plot showing the relationship between the minimum and maximum area (vertical lines) of the recognized landslides for each physiographic/morphological domain and the measured slope gradients (horizontal lines); T.C.: Tectonically-controlled. 
In such setting, sediments cannot accumulate over large areas and for long time spans, giving rise to large-scale failures, as typically observed on the mid and lower continental slopes [30-32]. This finding agrees with results from submarine landslide inventories recognized in other steep and geologically-active areas, such as in the Gulf of Corinth [33], western Messina Strait [34], Gulf of Naples and surrounding areas [35] and offshore Pontine Islands [36,37]. Besides the role of slope gradients, the size of the landslides is also influenced by the specific setting where landslide formed. Indeed, the smaller size of landslides in canyon headwalls with respect to canyons flanks and tectonically-controlled escarpments can be explained by considering that canyon headwalls are smaller and have a confined setting with respect to the canyon flanks and tectonically controlled scarps. Moreover, canyon headwalls are very dynamic environments in the study area, because they occur in shallow-water where cyclic loading generated by storm-waves may trigger submarine slope instability [4] and they are often located just off the river mouth of steep river courses with torrential regime (for instance at Bagnara Channels in Figure 3b), frequently affected by flash-flood generated hyperpycnal flows [25]. Canyon headwall are thus favorable settings for the development of frequent but small-size landslides, as testified by the occurrence of small retrogressive failures recognized through repeated bathymetric surveys at the headwall of Gioia Canyon and Bagnara Channels [27]. Further evidence of very recent sedimentary dynamics in these sectors is witnessed by the recognition of crescent-shaped bedforms in their thalweg, similar in size and morphology to the bedforms recognized in active channel/canyon elsewhere [38,39].

Steep gradients are also likely responsible for the disintegrative-like behavior characterizing most of these landslides [31], i.e. scars having a smooth morphology and associated landslide deposits not recognizable on the bathymetry. This behavior might be related to the fact that slide sediment either lost cohesion during failure or failed as a cohesive mass but disintegrated downslope due to the low mobilized volume and high energy (steep gradients and fall height). In this regard, it should be considered that the total fall height of the slope failures seems also to control the degree of the disintegration of the failed material. In fact, only for those scars located in the lower part of the steep flank of Capo Vaticano ridge, the related landslide deposits are still recognizable on bathymetry (Scars 1 and 2 in Figure 4b). This evidence is consistent with what was observed along other tectonically-controlled scarps, as, for instance, on the intraslope Palmarola ridge [40].

\subsubsection{Large-Size and Isolated Landslides on the Open Slopes}

Slope failures occurring in open slopes have the largest dimension (Table 1 and Figure 6) and most of them can be interpreted as the result of translational failure in relation to their slope-parallel bedding and fairly constant height of the main head-scarp, similarly to what was observed in other continental margins [32]. However, despite that these slides are close to each other and share similarities in size and failure mechanism, they show significant morphological differences in the headwall, translational and toe domain, suggesting different post-failure evolution mechanisms (e.g. disintegrative-like vs cohesive-like behavior). Such differences can be related to changes in material properties, depth of the failure plane, slope gradients and frontal confinement [40-43]. In the case of the Cape Vaticano ridge, the cohesive-type landslide (Scar3 in Figure 5a) was confined downslope by the northern levee of the Mesima Canyon with respect to the less confined setting of the nearby disintegrative-like landslide (Scar4 in Figure 5a). It is also noteworthy that the disintegrative-like slide is characterized by a lower height and slope gradients of the head-scarp with respect to the cohesive-like landslide, indicating a failure occurring within a weaker or less cohesive material [44]. In the case of CVSC, cohesive-like slides preferentially occur in the northern part of the CVSC, where mixed turbidite-contourite deposits are present, while disintegrative-like slides mainly affected the contourite drifts developed in southern part (Figure 5b; [29]). This distribution suggests that the different post-failure behavior of the recognized slides can be due to the difference in sediment type (mixed turbidite-contourite deposits vs contourites) mobilized during the failure events along with the occurrence of steep gradients on the seaward side of the contourite drifts. 


\subsection{Preliminary Considerations on the Potential Geohazard Associated with the Submarine Mass Movements in the Calabro-Tyrrhenian Continental Margin}

In this section, we attempt to roughly assess the hazard potential associated with the recognized landslide scars. On the whole, the hazard related to the landslides affecting open slopes can be considered overall low, as these events are relatively few and they commonly occur at depths greater than $-120 \mathrm{~m}$. In this depth range, their size is likely not able to generate significant tsunami waves for surrounding coastal sectors by comparison with the tsunamigenic potential roughly estimated for similar landslides occurring in the same depth range in the nearby areas $[35,45]$ using semi-empirical equations available in the literature [46]. Similar considerations can be applied also to the small- and medium-size disintegrative-like affecting the tectonically-controlled escarpments and canyons flanks present in the area based on their size and depth range. However, we are aware that a more reliable geo-hazard definition of such slope failures would require a detailed characterization of the single slope failures (with seismic profiles, cores and in-situ measurements) coupled with a more rigorous computation of their tsunamigenic potential, but this is beyond the aim of this paper.

On the contrary, the hazard can be considered markedly higher for slope failures occurring at the canyon headwall of the Gioia Canyon and Bagnara Channels, because of the retrogressive erosion that commonly characterizes the evolution of canyon heads and their proximity to the coast (depths $<10 \mathrm{~m}$ and distance of few hundreds of meters). In such areas, retrogressive erosion processes can cause both the failure of coastal areas/infrastructures and small tsunami waves, as recently testified by the $5 \times 10^{6} \mathrm{~m}^{3}$ of material failed at the head of the Gioia Canyon in 1977 during the harbor construction (Figure $4 \mathrm{a}$ and [47]). It is noteworthy that a similar tsunamigenic landslide occurred two years later off Nice at the head of Var Canyon during the enlargement of the harbor, causing several damages and casualties [8]. Another relevant source of hazard in the study area is represented by rocky coastal failures that can affect the coastal range, whose blocky deposits are recognized in the submarine setting, as witnessed by the tsunamigenic coastal failure that occurred in 1783 nearby Scilla village that caused over 1500 casualties. The occurrence of such landslides is favored by the active fault systems affecting the coastal range, decreasing the shear strength of the outcropping metamorphic-crystalline basement, and they can be triggered by the frequent and strong seismicity present in the area.

\subsection{Conclusions}

This study has focused on the distribution and variability of landforms related to submarine mass movement along the tectonically-active Calabro-Tyrrhenian margin. Results indicate that distribution and morphology of these features are not random, but they are strictly related to the physiographic/morphological domains where slope failures develop. Small disintegrative-type slides mainly occur in the areas with the steeper gradients, such as canyons and tectonically-controlled scarps. Differently, larger and isolated landslides occur in open slopes, even if they can be characterized by a large variability of post-failure behavior. Cohesive-like and disintegrative-like slope failures can occur also at short distance in relation to difference in the mechanical properties of the mobilized material, slope gradients and degree of confinement. A peculiar case is represented by the Capo Vaticano Scar complex, whose formation can be related to the presence of a mixed turbidite-contourite systems in the upper continental slope/outer shelf sector.

In the study area, the hazard related to submarine mass-movements can be significant, especially for coastal rocky landslides and retrogressive slides at the headwall of shelf-indenting canyons/channels. These events can cause damage to coastal infrastructures and/or casualties as demonstrated by historical tsunamigenic events associated with the 1783 Scilla and 1979 Gioia Tauro slope failures.

In conclusion, this study demonstrates the importance and need of high-resolution marine studies in geologically-active areas, whose morphological evolution is strongly controlled by a large suite of mass-wasting processes ranging at different spatial scales. This can also provide preliminary considerations for the associated hazard assessment, a particularly relevant issue in strongly exploited coastal/marine settings, such as those present in the Mediterranean Sea. 
Author Contributions: Conceptualization, D.C.; Funding acquisition, F.C.; Investigation, A.B., D.C., F.C. and E.M.; Visualization, D.C.; Writing - original draft, D.C., A.B., E.M. and D.R.

Funding: The research was funded by the Italian MaGIC (Marine Geohazards along the Italian Coasts) Project and carried out in the framework of RITMARE (Ricerca ITaliana per il MARE) Project.

Acknowledgments: We acknowledge the crews of R/V Urania and Minerva Uno (CNR) together with the researchers and students that took part in the oceanographic cruise. Daniele Casalbore and David Casas also thank the research funding provided by "Progetto di Ateneo 2016" of the University Sapienza of Rome and the Spanish Project Fauces: CTM2015-65461-C2-1-R. The comments of Rajasmita Goswami and two anonymous reviewers are also acknowledged.

Conflicts of Interest: The authors declare no conflict of interest.

\section{References}

1. Masson, D.G.; Harbitz, C.B.; Wynn, R.B.; Pedersen, G.; Løvholt, F. Submarine landslides: Processes, triggers and hazard prediction. Philos. Trans. R. Soc. A 2006, 364, 2009-2039. [CrossRef] [PubMed]

2. Urlaub, M.; Talling, P.J.; Masson, D.G. Timing and frequency of large submarine landslides: Implications for understanding triggers and future geohazard. Quat. Sci. Rev. 2013, 72, 63-82. [CrossRef]

3. Moscardelli, L.; Wood, L. Morphometry of mass transport deposits as a predictive tool. Geol. Soc. Am. Bull 2016, 128, 47-80. [CrossRef]

4. Locat, J.; Lee, H.J. Submarine landslides: Advances and challenges. Can. Geotech. J. 2002, 39, $193-212$. [CrossRef]

5. Harbitz, C.B.; Løvholt, F.; Bungum, H. Submarine landslide tsunamis: How extreme and how likely? Nat. Hazards 2014, 72, 1341-1374. [CrossRef]

6. Longva, O.; Janbu, N.; Blikra, L.H.; Bøe, R. The 1996 Finneidfjord slide: Seafloor failure and slide dynamics. In Submarine Mass Movements and Their Consequences; Locat, J., Mienert, J., Eds.; Springer: Dordrecht, The Netherlands, 2003; pp. 531-538.

7. Casalbore, D.; Bosman, A.; Chiocci, F.L. Study of recent small-scale landslides in geologically active marine areas through repeated multibeam surveys: Examples from the Southern Italy. In Submarine Mass Movement and Their Consequences, Advances in Natural and Technological Hazards Research; Yamada, Y., Kawamura, K., Ikehara, K., Ogawa, Y., Urgeles, R., Mosher, D., Chaytor, J., Strasser, M., Eds.; Springer: Heidelberg, Germany; Cham, Switzerland, 2012; Volume 31, pp. 573-582.

8. Sultan, N.; Savoye, B.; Jouet, G.; Leynaud, D.; Cochonat, P.; Henry, P.; Stegmann, S.; Kopf, A. Investigation of a possible submarine landslide at the Var delta front (Nice continental slope, southeast France). Can. Geotech. J. 2010, 47, 486-496. [CrossRef]

9. Chiocci, F.L.; Romagnoli, C.; Tommasi, P.; Bosman, A. Stromboli 2002 tsunamigenic submarine slide: Characteristics and possible failure mechanisms. J. Geophys. Res. 2008, 113, B10102. [CrossRef]

10. Chiocci, F.L.; Casalbore, D. Unexpected fast rate of morphological evolution of geologically-active continental margins during Quaternary: Examples from selected areas in the Italian seas. Mar. Petrol. Geol. 2017, 82, 154-162. [CrossRef]

11. Malinverno, A.; Ryan, W.B.F. Extension in the Tyrrhenian sea and shortening in the Apennines as result of arc migration driven by sinking of the lithosphere. Tectonics 1986, 5, 227-245. [CrossRef]

12. Fabbri, A.; Ghisetti, F.; Vezzani, L. The Peloritani-Calabria range and the Gioia basin in the Calabrian arc (Southern Italy): Relationships between land and marine data. Geol. Romana 1980, 19, 131-150.

13. Gamberi, F.; Marani, M. Hinterland geology and continental margin growth: The case of the Gioia Basin (Southeastern Tyrrhenian Sea). Geol. Soc. Lond. Spec. Publ. 2006, 262, 349-363. [CrossRef]

14. CPTI Working Group. Catalogo Parametrico dei Terremoti Italiani, version 2004 (CPTI04). INGV: Bologna, Italy. Available online: http://emidius.mi.ingv.it/CPTI (accessed on 10 October 2018).

15. Casas, D.; Chiocci, F.; Casalbore, D.; Ercilla, G.; de Urbina, J.O. Magnitude-frequency distribution of submarine landslides in the Gioia Basin (southern Tyrrhenian Sea). Geo-Mar. Lett. 2016, 36, 405-414. [CrossRef]

16. Tortorici, G.; Bianca, M.; de Guidi, G.; Monaco, C.; Tortorici, L. Fault activity and marine terracing in the Capo Vaticano area (southern Calabria) during the Middle-Late Quaternary. Quat. Int. 2003, 101-102, 269-278. [CrossRef] 
17. Lentini, F.; Carbone, S.; Guarnieri, P. Collisional and post-collisional tectonics of the Apenninic-Maghrebian Orogen (Southern Italy). In Postcollisional Tectonics and Magmatism in the Eastern Mediterranean Region; Dilek, Y., Pavlides, S., Eds.; Geological Society American: Boulder, CO, USA, 2006; Volume 409, pp. 57-81.

18. Antonioli, F.; Ferranti, L.; Lambeck, K.; Kershaw, S.; Verrubbi, V.; DaiPra, G. Late Pleistocene to Holocene record of changing uplift rates in southern Calabria and northeastern Sicily (southern Italy, Central Mediterranean Sea). Tectonophysics 2006, 422, 23-40. [CrossRef]

19. Sabato, L.; Tropeano, M. Fiumara: A kind of high hazard river. Phys. Chem. Earth A/B/C 2004, 29, 707-715. [CrossRef]

20. Chiocci, F.L.; Casalbore, D. Submarine gullies on Italian upper slopes and their relationship with volcanic activity revisited 20 years after Bill Normark's pioneering work. Geosphere 2011, 7, 1-11. [CrossRef]

21. Casalbore, D.; Chiocci, F.L.; Scarascia Mugnozza, G.; Tommasi, P.; Sposato, A. Flash-flood hyperpycnal flows generating shallow-water landslides at Fiumara mouths in Western Messina Straits (Italy). Mar. Geophys. Res. 2011, 32, 257-271. [CrossRef]

22. Casalbore, D.; Ridente, D.; Bosman, A.; Chiocci, F.L. Depositional and erosional bedforms in Late Pleistocene-Holocene pro-delta deposits of the Gulf of Patti (southern Tyrrhenian margin, Italy). Mar. Geol. 2017, 385, 216-227. [CrossRef]

23. Gamberi, F.; Rovere, M.; Marani, M. Mass-transport complex evolution in a tectonically active margin (Gioia Basin, Southeastern Tyrrhenian Sea). Mar. Geol. 2011, 279, 98-110. [CrossRef]

24. Bozzano, F.; Lenti, L.; Martino, S.; Montagna, A.; Pacielloc, A. Earthquake triggering of landslides in highly jointed rock masses: Reconstruction of the 1783 Scilla rock avalanche (Italy). Geomorphology 2011, 129, 294-308. [CrossRef]

25. Casalbore, D.; Bosman, A.; Ridente, D.; Chiocci, F. Coastal and submarine landslides in the tectonically-active Tyrrhenian Calabrianmargin (Southern Italy): Examples and geohazard implications. In Submarine Mass Movements and Their Consequences. Advances in Natural and Technological Hazards Research; Krastel, S., Ed.; Springer: Heidelberg, Germany; Cham, Switzerland, 2016; Volume 37, pp. 261-269. [CrossRef]

26. Casalbore, D.; Falcini, F.; Martorelli, E.; Morelli, E.; Bosman, A.; Calarco, M.; Chiocci, F.L. Characterization of overbanking features on the lower reach of the Gioia-Mesima canyon-channel system (southern Tyrrhenian Sea) through integration of morpho-stratigraphic data and physical modelling. Prog. Oceanogr. 2018. [CrossRef]

27. Bosman, A.; Casalbore, D.; Dominici, R. Cyclic Steps at the Head of Channelized Features Along the Calabrian Margin (Southern Tyrrhenian Sea, Italy). In Atlas of Bedforms in the Western Mediterranean; Guillén, J., Acosta, J., Chiocci, F., Palanques, A., Eds.; Springer: Heidelberg, Germany; Cham, Switzerland, 2017; pp. $229-233$. [CrossRef]

28. Casalbore, D.; Martorelli, E.; Bosman, A.; Morelli, E.; Latino Chiocci, F. Failure dynamics of landslide scars on the lower continental slope of the Tyrrhenian Calabrian margin: Insights from an integrated morpho-bathymetric and seismic analysis. In Subaqueous Mass Movements and Their Consequences: Assessing Geohazards, Environmental Implications and Economic Significance of Subaqueous Landslides; Lintern, D.G., Mosher, D.C., Moscardelli, L.G., Bobrowsky, P.T., Campbell, C., Chaytor, J.D., Clague, J.J., Georgiopoulou, A., Lajeunesse, A., Normandeau, A., et al., Eds.; Geological Society, Special Publications: London, UK, 2018; Volume 477, p. 416. [CrossRef]

29. Martorelli, E.; Bosman, A.; Casalbore, D.; Falcini, F. Interaction of down-slope and along-slope processes off Capo Vaticano (southern Tyrrhenian Sea, Italy), with particular reference to contourite-related landslides. Mar. Geol. 2016, 378, 43-55. [CrossRef]

30. Booth, J.S.; O'Leary, D.W.; Popenoe, P.; Danforth, W.W. U.S. Atlantic continental slope landslides: Their distribution, general attributes, and implications. In Submarine Landslides: Selected Studies in the U.S. Exclusive Economic Zone; Schwab, W.C., Lee, H.J., Twichell, D.C., Eds.; U.S. Geological Survey Bulletin: Mount Spurr Volcano, AK, USA, 1993; pp. 14-22.

31. McAdoo, B.G.; Pratson, L.F.; Orange, D.L. Submarine landslide geomorphology, US continental slope. Mar. Geol. 2000, 169, 103-136. [CrossRef]

32. Hühnerbach, V.; Masson, D.G. Landslides in the North Atlantic and its adjacent seas: An analysis of their morphology, setting and behaviour. Mar. Geol. 2004, 213, 343-362. [CrossRef] 
33. Charalampakis, M.; Stefatos, A.; Hasiotis, T.; Ferentinos, G. Submarine Mass Movements on an active fault system in the Central Gulf of Corinth. In Submarine Mass Movements and Their Consequences. Advances in Natural and Technological Hazards Research; Lykousis, V., Sakellariou, D., Locat, J., Eds.; Springer: Dordrecht, The Netherlands; Cham, Switzerland, 2007; Volume 27.

34. Goswami, R.; Mitchell, N.C.; Argnani, A.; Brocklehurst, S.H. Geomorphology of the western Ionian Seabetween Sicily and Calabria, Italy. Geomar. Lett. 2014, 34, 419-433.

35. Alberico, I.; Budillon, F.; Casalbore, D.; Di Fiore, V.; Iavarone, R. A critical review of potential tsunamigenic sources as first step towards the tsunami hazard assessment for the Napoli Gulf (Southern Italy) highly populated area. Nat. Hazards 2018, 92, 43-76. [CrossRef]

36. Chiocci, F.L.; Martorelli, E.; Bosman, A. Cannibalization of a continental margin by regional scale mass wasting: An example from the central Tyrrhenian Sea. In Submarine Mass Movements and Their Consequences. Advances in Natural and Technological Hazards Research; Locat, J., Miniert, J., Eds.; Springer: Dordrecht, The Netherlands; Cham, Switzerland, 2003; Volume 19, pp. 409-416.

37. Casalbore, D.; Bosman, A.; Martorelli, E.; Sposato, A.; Chiocci, F.L. Mass wasting features on the submarine flanks of Ventotene volcanic edifice (Tyrrhenian Sea, Italy). In Submarine Mass Movements and Their Consequences, 6th International Symposium. Advances in Natural and Technological Hazards Research; Krastel, S., Behrmann, J.-H., Völker, D., Stipp, M., Berndt, C., Urgeles, R., Chaytor, J., Huhn, K., Strasser, M., Harbitz, C.B., Eds.; Springer: Dordrecht, The Netherlands; Cham, Switzerland, 2016; Volume 37, pp. 285-293.

38. Paull, C.K.; Ussler, W., III; Caress, D.W.; Lundsten, E.; Barry, J.; Covault, J.A.; Maier, K.L.; Xu, J.P.; Augenstein, S. Origins of large crescent-shaped bedforms within the axial channel of Monterey Canyon. Geosphere 2010, 6, 755-774. [CrossRef]

39. Hughes Clarke, J.E.; VidieraMarques, C.R.; Pratomo, D. Imaging active mass-wasting and sediment flows on a Fjord Delta, Squamish, British Columbia. In Submarine Mass Movements and Their Consequences. Advances in Natural and Technological Hazards Research; Mosher, D.C., Shipp, C., Moscardelli, L., Chaytor, J., Baxter, C., Lee, H., Urgeles, R., Eds.; Springer: Dordrecht, The Netherlands; Cham, Switzerland, 2014; Volume 37, pp. 249-260.

40. Casalbore, D.; Bosman, A.; Chiocci, F.L.; Ingrassia, M.; Macelloni, L.; Sposato, A.; Martorelli, E. New insights on failure and post-failure dynamics of submarine landslides on the intra-slope Palmarola ridge (Central Tyrrhenian Sea). In Submarine Mass Movements and Their Consequences, 6th International Symposium. Advances in Natural and Technological Hazards Research; Krastel, S., Behrmann, J.-H., Völker, D., Stipp, M., Berndt, C., Urgeles, R., Chaytor, J., Huhn, K., Strasser, M., Harbitz, C.B., Eds.; Springer: Dordrecht, The Netherlands; Cham, Switzerland, 2016; Volume 37, pp. 93-101.

41. Frey-Martínez, J.; Cartwright, J.; James, D. Frontally confined versus frontally emergent submarine landslides: A 3D seismic characterisation. Mar. Pet. Geol. 2006, 23, 585-604. [CrossRef]

42. Minisini, D.; Trincardi, F.; Asioli, A.; Canu, M.; Foglini, F. Morphologic variability of exposed mass-transport deposits on the eastern slope of Gela Basin (Sicily channel). Basin Res. 2007, 19, 217-240. [CrossRef]

43. Moernaut, J.; De Batist, M. Frontal emplacement and mobility of sublacustrine landslides: Results from morphometric and seismostratigraphic analysis. Mar. Geol. 2011, 285, 29-45. [CrossRef]

44. Morgenstern, N.R. Submarine slumping and the initiation of turbidity currents. In Marine Geotechnique; Richards, A., Ed.; University of Illinois Press: Urbana, IL, USA, 1967; pp. 189-210.

45. Casalbore, D.; Romagnoli, C.; Bosman, A.; Chiocci, F.L. Potential tsunamigenic landslides at Stromboli Volcano (Italy): Insight from marine DEM analysis. Geomorphology 2011, 126, 42-50. [CrossRef]

46. Watts, P.; Grilli, S.T.; Kirby, J.T.; Fryer, G.J.; Tappin, D.R. Landslide tsunami case studies using a Boussinesq model and a fully nonlinear tsunami generation model. Nat. Hazards Earth Syst. Sci. 2003, 3, 391-402. [CrossRef]

47. Colantoni, P.; Gennesseaux, M.; Vanney, J.R.; Ulzega, A.; Melegari, G.; Trombetta, A. Processi dinamici del canyon sottomarino di gioia tauro (Mare Tirreno). Giorn. Geol. 1992, 3, 199-213.

(C) 2019 by the authors. Licensee MDPI, Basel, Switzerland. This article is an open access article distributed under the terms and conditions of the Creative Commons Attribution (CC BY) license (http://creativecommons.org/licenses/by/4.0/). 